\title{
The impact of privatization on financial performance of state - owned enterprises: A case study of the Jordanian Cement Factories Company
}

\author{
Khalaf Al-Taani \\ Department of Banking \& Finance, Faculty of Finance \& Administrative Sciences, Irbid National University, Irbid - Jordan \\ Email address: \\ ktaani@yahoo.com,Dr.ktaani@inu.edu.jo \\ To cite this article: \\ Khalaf Al-Taani. The Impact of Privatization on Financial Performance of State - Owned Enterprises: A Case Study of the Jordanian \\ Cement Factories Company. Journal of Finance and Accounting. Vol. 1, No. 3, 2013, pp. 46-54. doi: 10.11648/j.jfa.20130103.12
}

\begin{abstract}
This study aimed at investigating the potential impact of privatization on the financial and operating performance of the Jordanian Cement Factories Company (JCFC) as an attempt to contribute to the debate on how the privatization of public enterprises may affect the financial and operational performance of these enterprises. The data were obtained from the annual reports of JCFC for five years before and five years after privatization. Performance criteria were calculated and compared to determine whether there are significant differences among them in the pre- and postprivatization periods. Related statistics of JCFC share performance were further compared with the market and industry indicators. The findings revealed that while privatization did not seriously affect JCFC's operating performance and profit, it led to liquidity improvement, debt reduction, improved investments, and a decline in overstaffing.
\end{abstract}

Keywords: Privatization, Market, Industry, Indicators, Jordanian Cement Factories Company

\section{Introduction and Background}

The efficiency of the social and economic infrastructure has been generally recognized as a critical factor in the development of any economy. Empirical research has shown State Owned Enterprises (SOEs) as relatively inefficient and often a drain on public treasury, which has promoted the concept of privatization, in which the economy is placed in the hands of private sector operators who have been known for their efficiency and competitive spirit, to evolve and be globally embraced.

In its narrow sense, the term privatization is frequently used to refer to the sale of the assets or shares of SOEs to individuals or private firms. However, in its broader sense, it refers to restricting the government's role and to put forward some methods or policies to strengthen free market economy, which entails more reliance on the private sector to meet the needs of society.

The Jordanian Government Privatization program and the government address before the parliament in March 1998 have defined privatization as the "redistribution of roles between the private and the public sectors". In addition, Article No. 3 of privatization Law No. 25 for the year 2000 defines privatization as "the adoption of an economic track which covers the public sector projects the nature of whose management requires running them on a commercial basis".

Privatization has become an important phenomenon in both developed and developing countries. Over the past decade, privatization attempts have been occurring at an increasing rate, especially in developing countries. The compound annual average growth rate was around $10 \%$ between 1990 and 2000, with global privatization revenues jumping from $\$ 25$ billion in 1990 to $\$ 200$ billion in 2000 . The number of countries that have implemented privatization polices has exceeded 110 , not to mention that privatization has touched almost every aspect of economic activity (Shhadeh, 2002).

The primary reason governments attempt to privatize SOEs is to improve the efficiency of these SOEs and, thus, to reduce the budgetary burden on the state. Other reasons for privatization attempts include raising revenues, creating popular capitalism, rewarding political loyalists, placating external financing agencies, decreasing the administrative burden of state bureaucracy, and making the private sector responsible for needed enterprise investments (Nellis, 1991).

In its adoption of privatization policies, Jordan has relied on a number of assumptions about the merits of 
privatization. These assumptions are supported by the experience of the countries which had preceded Jordan in privatizing SOEs. The most prominent of these assumptions is that private ownership leads to the improvement of the performance and efficiency of companies.

Although Jordan's first privatization attempts started in 1996, the literature on privatization in Jordan lacks empirical research which aims at scientifically and objectively assessing this experience to examine the degree of success of these privatization attempts in terms of realization of their desired outcomes. Thus, the purpose of the present study is to empirically investigate the effect of privatization on the financial and operational performance of the Jordanian Cement Factories Company (henceforth, JCFC) as an example of these privatization attempts.

Different theoretical views underlie why SOEs are less effective than private counterparts. Shapiro and Willig (1990) adopt a social view in which SOEs are seen as instruments capable of curing market failures by implementing prices polices that take account of social marginal costs. Shleifer and Vishny (1994) adopt a political view which sees that private firms should be less subject to political interference to avoid excessive employment, poor choices of product and location, lack of investments, and ill-defined incentives for managers.

SOEs may be more susceptible to pressure from interest groups, while private firms can focus solely on maximizing profits. Private investors tend to have the foresight to acquire assets that can be sold, whereas the electoral assets enjoyed by politicians tend to be more fleeting and shortlived (Phelps, 1992).

Privatization in Jordan has not been an economic luxury, a fad, or a simulation of other countries' experiences but rather the result of rigorous surveys and investigation of public-sector projects which revealed a large degree of inefficiency in the administrative and employment policies, squander of public funds, administrative archaism, substandard services and high indebtedness. The private sector firms, however, have been found to yield higher returns and to generate better job opportunities.

Privatization in Jordan has been reported to have various objectives ranging from putting an end to the continuous depletion of public funds, which resulted from the treasury's support of loss-making projects, to attracting foreign investments. More specifically, article No. 3 of the privatization Law No 25 for the year 2000 defines the objectives of privatization as follows:

1. raising the efficiency, productivity and competitiveness of enterprises;

2. encouraging local, Arab, and international investments by providing a favorable investments environment;

3. stimulating private savings towards long-term investments to strengthen the local capital market and national economy;

4. Alleviating the debt burden of the treasury by ceasing its obligation to offer aid and loans to unprofitable enterprises; and

5. Managing economic enterprises with modern methods.

Privatization was part of the overall economic adjustment program in the aftermath of the economic crisis that befell the country in the early nineties. Simultaneously, new international economic developments were taking place in terms of globalization, rise of competitiveness, lifting of customs and administrative barriers to liberate world economy, capital flows, and communications and information revolution. This prompted Jordan to open up to the world through partnership agreements with the European Union (EU) and accession to the World Trade Organization (WTO) or through opting for a free Arab trade Zone and penetrating new unconventional markets.

The main issues slowing down the privatization program included the question of the absorptive capacity of the Jordanian financial market, public preferences on strategic or foreign ownership, and public perceptions of the impact of privatization on labor and consumer prices. Before privatization could proceed, these issues needed to be addressed and consensus built.

Privatization in Jordan is executed within a clear-cut institutional framework where responsibility is shared by a number of agencies which set policies, provide oversight and implement the privatization program. The most important of these agencies are the cabinet, the Higher Council for Privatization (HCP), the Executive Privatization Commission (EPC), the Privatization steering committees, and the bodies concerned with the projects which are subject to the privatization process. In the year 1999 H. M. King Abdullah 11 set up the Advisory Economic Council which has come to play a significant role in the approval of privatization in various sectors.

A number of justifications may be given to explain the causes of Jordan's inclination to adopt privatization policies. Among the most important are the following:

1. The failure of the economic sector restructuring programs which started in the 1970's;

2. The Jordanian economic reform manifested in the change of the form of ownership and its role in the improvement of companies' general performance;

3. The public sector's inability to keep abreast of production processes in local and foreign private sectors;

4. Lifting the burden on the budget through stopping the subsidy and reducing the size of internal and external indebtedness through reduction of lending; and

5. Ending the government intervention in the production processes in some sectors after it proved to be an obstacle to the expansion of investment and improvement of productivity.

The Jordanian privatization program is ranked as one of, if not the most, successful programs in the Middle East. To date, it has achieved the following: 
1. A $33 \%$ sale of the government shares in the JCFC to the private sector;

2. Granting four bus concessions of the public transport corporation (PTC)in the Greater Amman area;

3. Granting a concession of the Ma'in Spa;

4. A $49 \%$ sale of the government shares in the Jordanian Telecommunications Corporation (JTC) to the private sector;

5. Contracting the water management of the Jordanian Water Authority (JWA) in the greater Amman area;

6. Divestituting government shares in 44 companies at approximately $\$ 137$ million with total proceeds in excess of $\$ 900$ million;

7. A large pipeline of activities of which some are just starting and others are drawing to a close. Of these transactions are Royal Jordanian Airlines, Jordan Phosphate Mining Company, Postal Services, Electricity Sector (distribution and generation), Assamra Water Treatment Plant, Royal Jordanian Air Academy, Customs Department Warehouses, and Petra Water Authority.

\section{Objective of the Study}

The main objective of this study is to evaluate the impact of privatization on the financial and operating performance of the Jordanian Cement Factories Company (JCFC). To achieve this objective, the study addresses the theoretical aspects of privatization by reviewing concepts, methods, impact, and experiences of some developing countries. The study attempts to contribute to the debate on how the privatization of public enterprises (represented here by the JCFC) may affect the financial and operational performance of these enterprises. More specifically, the study attempts to answer the following two questions:

1. Has privatization led to the improvement of the financial and operational performance of the JCFC?

2. Has privatization been conducive to the improvement of the JCFC performance efficiency indicators such as profitability, operative efficiency, investment expenditure, and financial elevation?

\section{Literature Review}

Some empirical research has been carried out in both developed and developing countries to examine the effect of privatization. The studies undertaken in the former attributed the superior efficiency of private firms to market structure rather than to ownership, while the few studies done in the pointed to marginal efficiency differences between public and private firms (Kikeri, Nellis, and Shirley, 1994).

Megginson, Nash and Van Randenborgh (1994) compared the pre- and post- privatization financial and operating performance of 61 firms from 18 (12 developed and 6 developing) countries and 32 industries over the period between 1961 and 1990. Megginson et al suggested that there is strong evidence that, after privatization, their sample firms become more profitable, increased their real sales and their investment spending, and improved their operating efficiency.

Earle and Estrin (1996) found empirical evidence that privatization in Russia impacted enterprise efficiency; however, the market structure and budget constraints decreased this effect. Earle and Estrin (1997) further found systematic effects of private ownership on several types of restructuring behavior and on labor productivity.

Grosfeld and Nivet (1997) showed that polish privatized firms invested more and had greater capacity to ensure higher output growth. In two related studies, Frydman, Rapaczynski, and Turkewitz (1997) and Frydman, Murphy, and Rapaczynski (1998) found that private ownership dramatically improved corporate revenue performance in the Czech Republic, Hungary and Poland although no comparable effect of ownership change on cost reduction was found.

Boubakri and Cosset (198) examined 79 newly partiallyor fully- privatized firms headquartered in 21developing countries (e.g. Bangladesh, India, Nigeria, Malaysia, and Tunisia) over the period from 1980 to 1990. Boubakri and Cosset reported that newly privatized firms exhibit significant increases in profitability, operating efficiency, capital investment spending, real sales, total employment, and dividends.

Al-Sumadi (1998) claimed that privatization in Jordan is a necessity, because of the weakness of the Jordanian public sector. He further revealed that the government is committed to privatization.

D'Souza and Megginson (1999) compared the pre- and post- privatization financial and operating performance of 85 companies in 28 countries and 21 industries that were privatized through public share offerings for the period between 1999 and 1996. D'Souza and Megginson reported that privatization has led to significant increase in profitability, output, operating efficiency and dividend payments as well as a significant decrease in leverage ratios. However, Ernst, Edward, Gegory, and Holt's (1999) examination of 6 Morocan privatized firms revealed that privatization has a negative or no effect on financial performance.

Osman (2000) explored changes in pre- privatization financial performance and activities of 24 cement companies. He reported statistically significance changes in net period profits and capacity utilization ratios and partially significant changes in investments and production levels in the pre- privatization and post- privatization periods. He further reported a statistically significant decrease in the number of employees and increase in productivity levels.

Perevalov, Gimadi, and Dobrodey, (2000) found empirical evidence on the effect of privatization on performance of medium, large, and extra- large Russian industrial enterprises. Perevalov, et al found that, on 
average, privatization produces performance improvements in operating profit margin and to some extent, in labor productivity.

In his examination of 69 Egyptian firms, Omran (2001) reported a positive relationship between ownership structure of companies and their efficiency. He further reported that privatized firms performed better than they had before privatization. Omran further concluded that general liberalization was more important than privatization in explaining behavior.

\section{Findings and Discussion}

The purpose of this study is to evaluate the impact of privatization on the financial and operating performance of the JCFC. The study is based on comparing different financial and operating performance criteria and ratios of the JCFC in the pre- privatization and post- privatization eras. These criteria include operating performance, profitability, liquidity, leverage, investment, and production level, production per worker, capacity utilization rate, and number of workers.

In order to analyze the performance of JCFC, the year of privatization was assigned a zero value and the average ratios of the company's performance were calculated. Data were obtained from the annual financial reports of JCFC five years before and five years after privatization. Performance criteria were calculated and compared to determine whether there are significant differences among them in the pre- and post- privatization periods. Related statistics of JCFC share performance were further compared with the market and industry indicators.

\subsection{Operating Performance}

This indicator measures management efficiency in using the available resources. Share turnover, assets turnover, working capital turnover and accounts receivable turnover were the primary indicators of operating performance used. Table (1) shows the mean values of operating performance indicators before and after privatization. Working capital and assets turnover show positive changes with mean values 14.44 and 0.03 , respectively. In other words, working capital increased from an average of -8.6 before privatization to 5.83 after privatization while assets turnover increased from an average of 0.57 before privatization to 0.60 after privatization. However, share turnover and accounts receivable turnover show negative changes before and after the privatization with mean values of -4.9 and -35.03 , respectively. More specifically, share turnover decreased from an average of 17.47 before privatization to one of 12.57 in the years after privatization while accounts receivable turnover decreased from an average of 49.7 in the years of preceding privatization to 14.67 in the years after privatization. This negative change in mean value of the accounts receivable turnover has lengthened the collection period from an average of 7.34 years before privatization to 24.88 years after privatization.

Table 1: The results of JCFC Operating Performance Ratios before and after Privatization

\begin{tabular}{llllll}
\hline Indicator & $\begin{array}{l}\text { Mean value before } \\
\text { privatization }\end{array}$ & $\begin{array}{l}\text { Mean vale after } \\
\text { privatization }\end{array}$ & $\begin{array}{l}\text { Mean change Due to } \\
\text { privatization }\end{array}$ & $\begin{array}{l}\text { Percentage of the } \\
\text { change }\end{array}$ & $\begin{array}{l}\text { Description of the } \\
\text { change }\end{array}$ \\
\hline Share Turnover & 17.47 & 12.57 & -4.9 & -28.04 & Negative \\
$\begin{array}{l}\text { Assets Turnover } \\
\text { Working Capital }\end{array}$ & 0.57 & 0.60 & 0.03 & 5.26 & Positive \\
$\begin{array}{l}\text { Turnover } \\
\begin{array}{l}\text { Accounts Receivable } \\
\text { Turnover }\end{array}\end{array}$ & -8.61 & 5.83 & 14.44 & 167.71 & Positive \\
$\begin{array}{l}\text { Average Collection } \\
\text { Period }\end{array}$ & 7.34 & 14.67 & -35.03 & -70.48 & Negative \\
\hline
\end{tabular}

The ratios are calculated by the researcher.

Privatization seems to have a huge positive affect on working capital turnover and a very small one on assets turnover before and after privatization. The results also show a negative effect on share turnover and accounts receivable turnover which has increased the average collection period. Thus, from an operational performance perspective, the results partially support the hypothesis that privatization does not have a positive effect on JCFC performance.

\subsection{Profitability}

Return on share, return on sales, return on investment, return on equity and return on market value are the indicators used to measure profitability. Table (2) summarizes these profit performance indicators. 
Table 2: The Results of JCFC Profitability Ratios before and after Privatization

\begin{tabular}{llllll}
\hline Indicator & $\begin{array}{l}\text { Mean value before } \\
\text { privatization }\end{array}$ & $\begin{array}{l}\text { Mean value after } \\
\text { privatization }\end{array}$ & $\begin{array}{l}\text { Mean change Due to } \\
\text { privatization }\end{array}$ & $\begin{array}{l}\text { Percentage of } \\
\text { Change }\end{array}$ & Change Description \\
\hline Return on Share & 0.16 & 0.12 & -0.04 & -25.00 & Negative \\
Return on Sales & 9.28 & 6.99 & -2.29 & -24.68 & Negative \\
Return on Investment & 5.26 & 5.39 & 0.13 & 2.47 & Positive \\
Return on Equity & 10.28 & 6.67 & -3.61 & -35.12 & Negative \\
$\begin{array}{l}\text { Return on Market } \\
\text { Value }\end{array}$ & 0.048 & 0.038 & -0.01 & -20.83 & Negative \\
\hline
\end{tabular}

The Ratios are calculated by the researcher.

Table (2) shows a small effect on return on investment as a result of privatization with a mean value of 0.13 while return on share, return on sales, return on equity and return on market value show negative changes after privatization was introduced with a mean values of $-0.04,-2.29,-3.61$, and -0.01 , respectively. In other words, return on sales and return on equity indicators have relatively larger negative decreases than other two indicators. Return on sales changed from an average of 9.28 before privatization to one of 6.99 after it. Similarly, return on equity decreased from an average of 10.28 in the years before privatization to 6.67 in the period following it.
In contrast, a slight positive change has occurred in return on investment as its mean value increased from 5.26 before privatization to 5.39 in the years after privatization. Based on the above five profitability indicators, the results seem to suggest that privatization does not lead to profit increase in JCFC.

\subsection{Liquidity}

The indicators of working capital and current ratio are used to gauge liquidity as shown in table (3).

Table 3: The Results of JCFC Liquidity Ratios before and after privatization

\begin{tabular}{llllll}
\hline Indicator & $\begin{array}{l}\text { Average before } \\
\text { privatization }\end{array}$ & $\begin{array}{l}\text { Average after } \\
\text { privatization }\end{array}$ & Average Change & $\begin{array}{l}\text { Percentage of } \\
\text { Change }\end{array}$ & Change Description \\
\hline Working Capital & -13.5 & 18.95 & 32.46 & 240.44 & positive \\
Current ratio & 0.75 & 1.69 & 0.91 & 116.67 & Positive \\
\hline
\end{tabular}

Ratios are calculated by the researcher.

Table (3) suggests that liquidity affects privatization positively based on calculations of working capital and current ratio, working capital was found to increase from an average of -13.5 before privatization to 18.96 after privatization while current ratio was found to rise from an average of 0.78 in the years before privatization to 1.69 in the period after it with positive mean values of 32.46 and 0.91, respectively. This indicates that current assets exceeded current liabilities after privatization was introduced, which indicates an evident improvement in performance after privatization, probably leading to liquidity improvement in JCFC.

\subsection{Leverage}

Debt to equity and debt to total assets were used as indicators of leverage, for they show the extent to which debt is used in JCFC capital structure. Table (4) summarizes related results.

Table 4: The Results of JCFC Leverage Ratios before and after privatization

\begin{tabular}{llllll}
\hline indicator & $\begin{array}{l}\text { Average before } \\
\text { privatization }\end{array}$ & $\begin{array}{l}\text { Average after } \\
\text { privatization }\end{array}$ & Average Change & $\begin{array}{l}\text { Percentage of } \\
\text { Change }\end{array}$ & Change Description \\
\hline Debts to equity & 95.66 & 54.26 & -41.4 & -43.28 & positive \\
Debts to assets & 48.82 & 34.63 & -14.19 & -29.07 & Positive \\
\hline
\end{tabular}

Ratios are calculated by the researcher. 
The ratio of debt to equity was found to decline from an average of 95.66 before privatization to 54.26 after it. By the same token, the debt to total assets ratio was found to decrease from an average of 48.82 in the period before privatization to 34.63 in the period following it. This indicates that the JCFC debt to equity and debt to assets ratios have largely decreased as a result of privatization with mean values of 41.4 and 29.07, respectively. The results seem to suggest that privatization could lead to debt reduction.

\subsection{Investment}

Turnover per share and market to book value were used in this category to measure JCFC investment, as shown in Table (5).

Table 5: The Results of JCFC Investment Ratios before and after privatization

\begin{tabular}{llllll}
\hline indicator & $\begin{array}{l}\text { Average before } \\
\text { privatization }\end{array}$ & $\begin{array}{l}\text { Average after } \\
\text { privatization }\end{array}$ & Average Change & $\begin{array}{l}\text { Percentage of } \\
\text { Change }\end{array}$ & Change Description \\
\hline $\begin{array}{l}\text { Turnover per share } \\
\text { Market value to book }\end{array}$ & 21.62 & 31.31 & 9.69 & 44.82 & positive \\
value & 2.15 & 1.79 & -0.36 & -16.74 & negative \\
\hline
\end{tabular}

Ratios are calculated by the researcher.

Table (5) shows an increase in the turnover per share from 21.62 in the years before privatization to 31.31 in the period after it with a positive average change of 9.69. However, the slight decrease in market to book value from 2.15 before privatization to 1.79 after privatization with a negative average change of 0.36 indicates that privatization may have an effect on JCFC investments. This seems to further suggest that investors' assessment of JCFC opportunities for growth and profitability will improve in the future.

\subsection{Other Indicators}

These indicators are actual production, capacity utilization, production per employee, and number of employees, whose effect is shown in Table (6).

Table 6: The Results of JCFC Investment Ratios before and after Privatization

\begin{tabular}{llllll}
\hline indicator & $\begin{array}{l}\text { Average before } \\
\text { privatization }\end{array}$ & $\begin{array}{l}\text { Average after } \\
\text { privatization }\end{array}$ & Average Change & $\begin{array}{l}\text { Percentage of } \\
\text { Change }\end{array}$ & Change Description \\
\hline $\begin{array}{l}\text { Actual production (in } \\
\text { ton) }\end{array}$ & 6455613 & 5065956 & -1389657 & -21.53 & negative \\
$\begin{array}{l}\text { Capacity utilization } \\
(\%)\end{array}$ & 84 & 62.85 & -21.15 & -25.18 & negative \\
$\begin{array}{l}\text { Production per } \\
\text { employee (in ton) }\end{array}$ & 2347 & 2440 & 93 & 3.96 & positive \\
$\begin{array}{l}\text { Production per } \\
\text { employee (in JD) }\end{array}$ & 3568 & 2351 & -1217 & -34.11 & negative \\
\hline $\begin{array}{l}\text { Number of employees } \\
\text { Nom }\end{array}$ & 2750 & 2331 & -419 & -15.24 & positive \\
\hline
\end{tabular}

The ratios are calculated by the researcher.

Table (6) shows that JCFC capacity utilization percentage decreased after privatization by $25.18 \%$, which may explain the decline in actual JCFC production. However, production per employee (in tons) increased by almost $4 \%$ after privatization, while the average production per employee (in JD) declined by $12.17 \%$. The average number of employees was found to decline from 2750 to 2331 employees after privatization, which means that JCFC may have been overstaffed in the years preceding privatization.

\subsection{Company's Share Performance Compared with the Market and Industry Indicators}

Table (7) shows JCFC's performance in relation to those of the industry and market during the period that preceded privatization. 
Table 7: Performance measure for the JCFC's Share compared to those of the industry and market before privatization

\begin{tabular}{|c|c|c|c|c|c|c|c|c|}
\hline Date & $\begin{array}{l}\text { Closing* } \\
\text { price for } \\
\text { (JCFC) }\end{array}$ & $\begin{array}{l}\text { Return } \\
\text { rate }\end{array}$ & $\begin{array}{l}\text { Industry** } \\
\text { indicator }\end{array}$ & $\begin{array}{l}\text { Return } \\
\text { rate }\end{array}$ & $\begin{array}{l}\text { Market*** } \\
\text { indicator }\end{array}$ & $\begin{array}{l}\text { Return } \\
\text { rate }\end{array}$ & $\begin{array}{l}\text { Share } \\
\text { return/industry } \\
\text { return (time) }\end{array}$ & $\begin{array}{l}\text { Share return/market } \\
\text { return(time) }\end{array}$ \\
\hline $\begin{array}{l}\text { Five years } \\
\text { Beginning } \\
1993\end{array}$ & 1.74 & 73.56 & 145.16 & -20.42 & 129.94 & 30.24 & 4.60 & 2.43 \\
\hline $\begin{array}{l}\text { Four years } \\
\text { Beginning } \\
1994\end{array}$ & 2.94 & 2.72 & 154.17 & -25.07 & 158.45 & 6.81 & 1.11 & 0.49 \\
\hline Ending 1997 & 3.02 & & 115.52 & & 169.24 & & & \\
\hline
\end{tabular}

Sources: * Jordanian Central Bank and Amman Financial Market Reports, 1993-2003.

** The Jordanian Central Bank Reports fro the period 1993-2003.

*** Amman Financial Market Website

Table (7) shows that the return per share for the JCFC has amounted to 4.6 times that of the industry and 2.43 times that of the market during the five years before privatization. Table 7 further shows the return per share for the JCFC has improved considerably amounting to 1.011 times that of the industry and 0.49 of the market during the four-year period beginning in 1994.

Table (8) shows JCFC's performance in relation to those of the industry and market in the period that followed privatization.

Table 8: Performance measure for the JCFC's Share compared to those of the industry and market after privatization

\begin{tabular}{lllll|llll}
\hline Date & $\begin{array}{l}\text { Closing* } \\
\text { price for } \\
\text { (JCFC) }\end{array}$ & $\begin{array}{l}\text { Return } \\
\text { rate }\end{array}$ & $\begin{array}{l}\text { Industry** } \\
\text { indicator }\end{array}$ & $\begin{array}{l}\text { Return } \\
\text { rate }\end{array}$ & $\begin{array}{l}\text { Market*** } \\
\text { indicator }\end{array}$ & $\begin{array}{l}\text { Return } \\
\text { rate }\end{array}$ & $\begin{array}{l}\text { Share return/industry } \\
\text { return (time) }\end{array}$ & $\begin{array}{l}\text { Share return/market } \\
\text { return(time) }\end{array}$ \\
\hline $\begin{array}{l}\text { Beginning } \\
1999\end{array}$ & 1.91 & & 76.93 & & 170.13 & & & \\
$\begin{array}{l}\text { Four years } \\
\text { ending } \\
\text { 2002 }\end{array}$ & 3.13 & 63.87 & 101.61 & 32.08 & 170.20 & 0.04 & 1.99 & 1552.42 \\
$\begin{array}{l}\text { Five years } \\
\text { ending } \\
\text { 2003 }\end{array}$ & 5.40 & 182.72 & 148.16 & 92.59 & 261.45 & 53.68 & 1.97 & 3.40 \\
\hline
\end{tabular}

Sources: * Jordanian Central Bank and Amman Financial Market Reports, 1993-2003.

** The Jordanian Central Bank Reports for the period 1993- 2003.

*** Amman Financial Market Website.

Table (8) shows that JCFC's return on share price has amounted to double that of the industry return and three times that of the market return during the five- year period that followed privatization.

Judging by the longer five- year period, it can be concluded that the JCFC return on stock was four and a half times that of the industry before privatization and twice that after privatization. It can be concluded that the return on stock of JCFC compared to that of the industry before privatization is better than that during the period following privatization. This may be attributed to that fact that economic and political situation in Jordan was more stable during the period between 1993 and 1997 (viz., before privatization) than that between 1998 and 2003 (viz., after privatization), which may have increased not only the total demand on cement for the construction sector but also the amount of cement exported to neighboring countries. This increased demand is evident in Table 6 which shows that the production volume before privatization had been more than that during the period following it.

Similarly, the JCFC return on stock was 20.4 and 3.4 times that of the market before and after privatization, respectively. Following privatization, the government was no longer in direct control of JCFC, which may have led to a reduction in inflated employment and, thus, in more productivity per employee. Furthermore, as shown in Table 2 above, the return on JCFC sales has plummeted considerably after privatization, which was partially rectified by the ensuing rise in cement prices in that period.

A close look at Table 8 reveals that a comparison between JCFC share return and that of the market shows a tremendous increase of the former following privatization, which may be attributed to the fact that the government was no longer in control of setting cement prices, not to mention the absence of rival local cement producers on the Jordanian market.

The above findings on JCFC market price performance during the five-year period before and the five-year period after privatization are inconclusive, as this indicator only represents returns of capital and, thus, does not constitute a viable unit of comparison. 


\section{Summary and Conclusions}

The objective of this study is to examine the impact of privatization on financial performance and operating performance of Jordan Cement Factories Company by using both descriptive and Quantitative ratio analysis. In order to achieve this objective, the study addressed the theoretical aspects of privatization, by reviewing concepts, objectives, methods, impacts, and experiences of some countries, particularly developing countries. Furthermore, the study concentrated on Jordan's privatization experience, which serves to establish a framework for the study and to derive the variables essential for conducting this examination.

To examine the performance of JCFC, the study followed the standard methodology of comparison used in the literature and empirical studies to compare the pre- and post- privatization financial and operating performance of the company that experienced full privatization through selling the government shares in 1998.

The result of the study revealed that there were positive improvements in the performance of JCFC after privatization in terms of liquidity and debt ratios compared to its performance before privatization.

The performance indicators showed significant increase in assets and working capital turnover, return on investment, as well as significant increase in share price. Moreover, the results indicated that the increase in production per employee in tone. On the other hand, the performance indicator of production per worker in JD and capacity utilization was decreased.

To ascertain whether this weakness of financial and operating performance of the JCFC could be attributed to privatization itself or to market conditions, the study compared profitability indicators of the company with similar indicators in related sectors. The results revealed significant increase in profitability of JCFC compared to related sectors' profitability.

To assess the impact of privatization on financial and operating performance of privatized Jordanian Companies, the study used financial analysis to identify the determinants of this performance weakness. The results confirm that privatization had, although relatively minimal positive impact on the JCFC performance indicators, and particularly operating efficiency, capital expenditure, leverage, and total number of employees.

Finally, an attempt was made to provide a set of various practical recommendations that may contribute to enhance the privatization policy. Prominent among these, the proper preparation of the economic environment, ensure an adequate competitive environment for all investors, and continuing the practice of the partial sale the government share in companies to foreign strategic partners as a proper method of privatization.

\section{References}

[1] Al- Sumadi, T . (1998). The Impacts of Privatization and Government Intervention in the Economy: An Empirical Analysis. Unpublished $\mathrm{PhD}$ Dissertation, Utah State University, U.S.A.

[2] Boubakri, N. and Cosset, J.C. (1998). The Financial and Operating Performance of Newly Privatized Firms: Evidence from Developing Countries. Journal of Finance, 53(3), 1081- 1110 .

[3] D' Souza, J. and Megginson, W. L. (1999). The Financial and Operating Performance of Privatized Firms during the 1990s. The Journal of Finance, 54(4), 1397 - 1438.

[4] D; Souza, J., Megginson, W., and Nash, R. (2001). Determinants of Performance Improvments in Privatized Firms; The of Restructuring and Corporate Governance. Retrieved November 19, 2005 from http://facultystaff.ou.edu/M/William.1.Megginson-1/prvsources.pd

[5] Earle, J. S. and Estrin, S. (1997). After Voucher Privatization: The structure of Corporate Ownership in Russian Manufacturing Industry. SITE Working paper. No. 120. Stockholm: Stockholm Institute of Transition Economics and East European Economies.

[6] Earle, J. S. and Estrin, S. (1996). Privatization versus Competition: Changing Enterprise Behavior in Russia. Working papers wp 96049, International Institute for Applied Systems Analysis.

[7] Ernst, U.F.W., Edwards, N., Gregory, P., and Holt, T. (1999). Assessing the Impacts of Privatization: The Experience of Morocco. ABT Association/United States Agency for International Development (USAID.

[8] Frydman, C.W., Murphy, K., and Rapaczynski, A. (1998). Capitalism with a Comrade's Face and Other Studies in Post communist Transition. Central European University Press (in cooperation with Cornell University Press).

[9] Frydman, C. W., Rapaczynski, A. and Turkewitz, J. (1997). Transition to a Private Property Regime in the Czech Republic and Hungary. In Woo, W., Parker, S and J. Sachs (Eds), Economies in Transition: Comparing Asia and Europe, MIT Press.

[10] Grosfeld, I. and Nivet, J.-F. (1997). Wage and Investment Behavior in Transition: Evidence from a Polish Panel Data Set. Social Science Research Network Working Paper Series.

[11] The Hashemite Kingdom of Jordan, (2003). Unpublished data, Department of Statistics.

[12] The Hashemite Kingdom of Jordan, (2000). Privatization Law No. (25).

[13] Karamustafa, O. (2000). An Analysis of Pre-Privatization and Post-Privatization Financial Performance and Activities of Privatized Cement Companies. Istanbul Stock Exchange Review, 4(16), 1-9.

[14] Kikeri, S., Nellis, J., and Shirley, M. (1994). Privatization: Lessons from Market Economies. The World Bank Research Observer, 9(2), 241-272. 
[15] Megginson, W., Nash, R., and Van Randenborgh, M. (1994). The Financial and Operating Performance of Newly privatized Firms: An International Empirical Analysis. Journal of Finance, 49, (2), 403-452.

[16] Nellis, J. (1991). Improving the Performance of Soviet Enterprises. World Bank - Discussion papers from the World Bank.

[17] Omran, M. (2001). The Performance of State- Owned Enterprises and Newly Privatized Firms: Empirical Evidence from Egypt. Working paper, The Arab Academy for Science and Technology, College of Management and Technology, Alexandria, Egypt.

[18] Perevalov, Y., Gimadi, I., and Dobrodey, V. (200). The Impact of Privatization on the Performance of Medium and Large Industrial Enterprises. Economic Education and Research Consortium Working Paper, 2k-01. Retrieved November 19, 2005 from http://www.eerc.ru/publications/workpapers/WP_2k-01e.pd.
[19] Phelps, E.S. (1992). Conclusions: to the $4^{\text {th }}$ Annual Villa Mondragone SeminaGrowth. In Rivista di politica Economica, 82, December 1992.

[20] Shahdeh, K.S. (2002). Lessons from Privatization in Arab Countries. Development Information Unit for Arab Countries, UNDP, 10-11.

[21] Shapiro, C. and Willig, R. (1990). Economic Rationales for the Scope of Privatization. In E. Suleiman and J. Waterbury, (Eds). The Political Economy of Public Sector Reform and Privatization (55-87). London: West view Press.

[22] Shirly, M. and Nellis, J. (1991). Public Enterprise reform: Lessons of Experience. EDI Development Studies. The World Bank.

[23] Shleifer, A. and Vishny, R. W. (1994). Politicians and Firms. Quarterly Journal of Economics, 109, 995- 1025. 